\title{
URGENSI IMPLEMENTASI LAPORAN BERKELANJUTAN (SUSTAINABILITY REPORTS) DI PERGURUAN TINGGI
}

\author{
Muhammad Miqdad1, Tomy Rizky Izzalqurny ${ }^{2}$ \\ Fakultas Ekonomi dan Bisnis, Universitas Jember, Jember
}

\begin{abstract}
Abstrak $\quad$ Tujuan dari penelitian ini adalah untuk menganalisis urgensi penerapan laporan berkelanjutan yang mendukung Sustainable Development Goals (SDGs) di tingkat perguruan tinggi. Penelitian ini menggunakan metode deskripsi kualitatif dengan pendekatan studi literatur dan studi kasus. Sumber data yang digunakan dalam studi literatur adalah artikel-artikel penelitian, buku, websites dan referensi ilmiah lainnya. Sumber data yang digunakan dalam studi kasus berupa data primer dari hasil survei dan wawancara pada salah satu perguruan tinggi negeri di Indonesia. Proses pengolahan dan analisis data meliputi reduksi data, penyajian data, dan pengambilan kesimpulan. Hasil penelitian menunjukkan bahwa laporan berkelanjutan pada saat ini telah diterapkan oleh berbagai organisasi dan telah memberikan banyak manfaat. Hal ini berarti bahwa pada perguruan tinggi, terutama yang berstatus BLU dan PTN-BH, pengungkapan laporan keberlanjutan secara rutin merupakan perwujudan transparansi tindakan organisasi terhadap lingkungan dan masyarakat yang merupakan contoh positif bagi organisasi lainnya sehingga perguruan tinggi dapat menjadi tonggak utama dalam mendorong terwujudnya SDGs diseluruh sektor di Indonesia.
\end{abstract}

Kata Kunci : laporan keberlanjutan, perguruan tinggi, SDGs

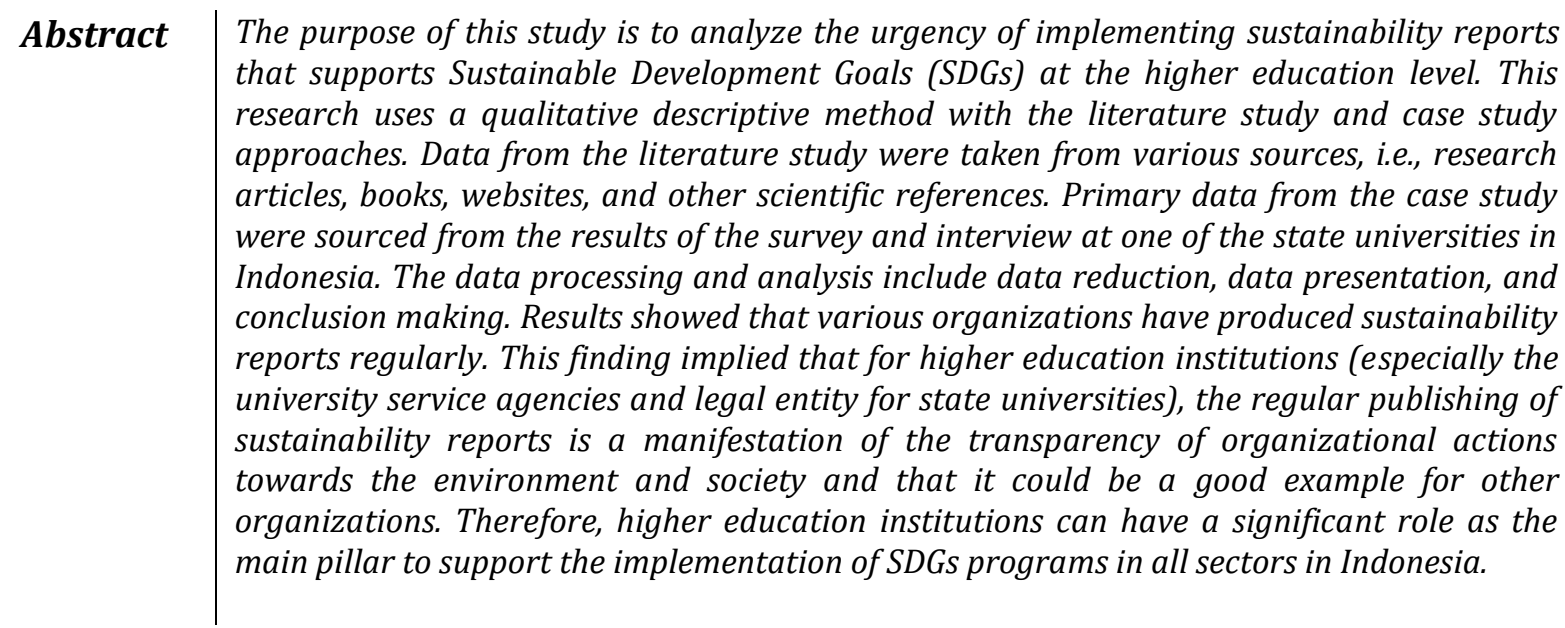

Keywords : $\quad$ higher education institutions, SDGs, sustainability reports

Fakultas Ekonomi dan Bisnis

Universitas Jember

E-mail: miqdad.feb@unej.ac.id 


\section{Pendahuluan}

Perkembangan ekonomi pada saat ini semakin mengembangkan suatu pengembangan berkelanjutan. Fokus pengembangan berkelanjutan sesuai dengan pertemuan PBB di New York pada September 2015 yang mencetuskan Sustainable Development Goals (SDGs). SDGs ini mempertimbangkan keadaan sosial serta lingkungan pada saat ini, dengan tujuan untuk pembangunan global tahun 2030 yang menjadi komitmen dari berbagai negara termasuk Indonesia (Alisjahbana et al., 2018). SDGs ini memiliki 17 tujuan serta 169 sasaran yang diharapkan dapat mengakhiri kemiskinan, serta menciptakan beragam kehidupan yang bermartabat, serta memberikan kesempatan yang sama di dunia ini (UN, 2015). Penerapan SDGs ini dibuktikan dengan adanya penerapan laporan berkelanjutan dalam laporan organisasi. Laporan keberlanjutan merupakan suatu laporan yang diterbitkan oleh suatu organisasi tentang dampak ekonomi, lingkungan, dan sosial dari kegiatan sehari-hari organisasi tersebut (Deegan, 2004, Nazari et al., 2015, Anugerah et al., 2018, Global Reporting Initiative, 2019).

Saat ini laporan berkelanjutan saat sudah diterapkan oleh beragam organisasi. Laporan berkelanjutan muncul karena terdapat kelemahan dari pelaporan keuangan karena tidak menunjukkan aspek sosial dan lingkungan dari aktivitas perusahaan. Pelaporan sosial dan lingkungan menunjukkan tindakan pertanggungjawaban dari perusahaan kepada aspek sosial dan lingkungan dari perusahaan, sehingga memunculkan isu keberlanjutan, sehingga mendorong perusahaan untuk membuat suatu laporan keberlanjutan (Yip et al., 2011). Penerapan laporan berkelanjutan merupakan salah satu wujud perusahaan dalam penerapan SDGs. Perusahaan dalam beberapa tahun terakhir mendukung terselenggara laporan tahunan seperti pengungkapan laporan berbasis sosial, lingkungan disamping laporan keuangan, berguna untuk mendukung kebutuhan dari para stakeholders (MartínezFerrero et al., 2013).

Perkembangan laporan keberlanjutan dalam perpektif historis berkembang mulai awal tahun 1970an dengan perkembangan laporan keuangan tradisional pada beberapa organisasi di negara barat yang turut melengkapi dengan laporan sosial (Hahn dan Kühnen, 2013). Setelah itu laporan berkelanjutan semakin berkembang hingga saat ini yang mendukung suatu SDGs. Perkembangan yang pesat ini dikarenakan tujuan dari laporan berkelanjutan yang menghubungkan manajemen sosial serta lingkungan dengan bisnis serta strategi manajemen, dengan demikian maka informasi lingkungan dan sosial terintegrasi dengan informasi ekonomi bisnis (Dienes et al., 2016). Memasukkan unsur sosial dan lingkungan dalam laporan keuangan juga didorong oleh adanya beragam kepentingan dari berbagai pihak.

Dalam penerapan laporan berkelanjutan, terdapat beragam pihak yang berkepentingan seperti: karyawan, pelanggan, pemasok, kreditor, dan beragam pihak lain, maka mendorong beragam kepentingan baik ekonomi, sosial maupun lingkungan untuk mendorong keberhasilan suatu organisasi (Hahn dan Kühnen, 2013, dan MartínezFerrero et al., 2013). Dengan demikian karena banyaknya pihak yang berkepentingan maka tanggung jawab perusahaan terhadap isu keberlanjutan dipengaruhi oleh banyak faktor, seperti tekanan regulator, meningkatnya rasa tanggung jawab sosial dan etika dari manajemen puncak, peluang bisnis baru, dan banyak faktor lain (Wijethilake, 2017). Penerapan laporan berkelanjutan selain mendukung penerapan SDGs juga akan memberikan banyak manfaat.

Peningkatan transparansi dalam tindakan perusahaan dan laporan keuangan akan meningkatkan nilai perusahaan, reputasi perusahaan, memungkinkan perbandingan terhadap pesaing, memberikan sinyal daya saing, memotivasi karyawan, dan mendukung informasi perusahaan dan proses pengendalian (Hahn dan Kühnen, 2013). Secara teoritis maka strategi berkelanjutan yang proaktif dapat meningkatkan performa keberlanjutan perusahaan, dengan memberikan manfaat bagi penerapan SDGs seperti mengurangi limbah, kepedulian terhadap sosial dan lingkungan, dengan demikian dapat meningkatkan reputasi sosial, 
meningkatkan preferensi dari pelanggan dan meningkatkan kemampuan untuk berinovasi yang baru. Dengan demikian maka banyak manfaat yang didapat dengan pelaporan laporan berkelanjutan.

Dengan melihat semakin berkembangnya laporan berkelanjutan berbasis SDGs, maka peneliti tertarik untuk mengetahui bagaimana urgensi penerapan laporan keberlanjutan di sektor publik. Hal ini dikarenakan sesuai dengan penelitian Dienes et al., (2016) menunjukkan bahwa terdapat perubahaan yang menunjukkan bahwa terdapat kepedulian yang meningkat terhadap laporan berkelanjutan, dan laporan berkelanjutan semakin menjadi bagian dari keputusan manajemen, praktik akuntansi, dan praktik pelaporan baik di perusahaan maupun di sektor publik. Sektor publik dalam penelitian ini difokuskan dalam penerapan laporan berkelanjutan di tingkat Perguruan Tinggi. Perguruan Tinggi dipilih karena mereka merupakan salah satu pihak yang dapat menunjang SDGs adalah pendidikan tinggi. Pendidikan tinggi utamanya Perguruan Tinggi sebagai salah satu pusat akademis dari suatu negara sangat dekat dengan aspek sosial dan lingkungan. Perguruan Tinggi memiliki peran penting dalam mengatasi tantangan global yang kritis saat ini dan mencapai SDGs (Sustainable Development Solutions Network, 2018).

\section{Metodologi}

Penelitian ini menggunakan deskripsi kualitatif dengan menggunakan studi literatur dan studi kasus. Penelitian studi literatur digunakan untuk mencari berbagai literatur dari penelitian sebelumnya untuk mengetahui bagaimana perkembangan laporan berkelanjutan hingga saat ini. Penelitian ini didukung juga dengan studi kasus untuk mendapatkan hasil yang lebih mendalam dalam suatu penelitian, karena metode penelitian studi kasus adalah suatu analisis mendalam serta kontekstual dari suatu situasi (Sekaran dan Bougie, 2013). Metode penelitian studi kasus merupakan suatu metode yang cocok digunakan pada permasalahan yang kompleks, sedang terjadi dan penting untuk dilakukan penelitian
(Cooper dan Morgan, 2008; Merriam dan Tisdell, 2015).

Sumber data yang digunakan dalam studi literatur ini adalah artikel-artikel penelitian, buku, websites maupun banyak referensi lain. Sumber data yang digunakan dalam studi kasus berupa data primer dari hasil survei dan wawancara pada salah satu Perguruan Tinggi negeri di Indonesia. Metode analisa data yang digunakan yaitu metode Miles dan Huberman (1984) meliputi:

a. Reduksi data. Peneliti dituntut untuk mengambil data lalu meringkas data, sehingga dibentuk kesimpulan yang dapat diverifikasi yang menjadi temuan penelitian.

b. Penyajian data. Peneliti mampu menyajikan data dengan ringkas, sehingga menajwab dan menjelaskan masalah dari penelitian.

c. Mengambil kesimpulan kemudian diverifikasi. Peneliti membuat kesimpulan dengan penyajian ringkas.

Keabsahan data perlu dilakukan untuk menjamin validitas dan reliabilitas penelitian. Peneliti menggunakan metode triangulasi data milik Moleong (2005). Peneliti melakukan triangulasi dengan menggunakan beberapa sumber data dalam penelitian, dengan menggunakan beragam literatur dan penguatan dengan mencari sumber data primer.

\section{Hasil dan Pembahasan}

\section{Transparansi dalam Laporan Perusahaan}

Pada beberapa tahun terakhir secara umum industri lebih sensitif terhadap lingkungan, dengan semakin tinggi level pengungkapan yang dilakukan. Joseph (2012) menyoroti bahwa pentingnya setiap organisasi memiliki alasan keberlanjutan yang tidak hanya pada aturan tetapi juga pada prinsip-prinsip. Fitur utama dalam prinsip laporan berkelanjutan ini merupakan transparansi.

Fernandez-Feijoo et al., (2013) menunjukkan bahwa transparansi merupakan kualitas dari komunikasi pertanggungjawaban sosial yang meningkatkan hubungan antara investor dan 
perusahaan. Laporan pertanggungjawaban sosial dalam laporan perusahaan merupakan alat komunikasi perusahaan yang digunakaan untuk mengungkapkan transparansi. Transparansi dalam laporan berkelanjutan akan memberikan akses kepada stakeholders untuk memahami area non keuangan.

Sun et al., (2010), Kim et al., (2011) serta Martínez-Ferrero et al., (2013) melakukan penelitian yang menunjukkan bahwa manajer yang semakin transparan dalam melaporkan tindakannya maka akan meminimalkan tindakan negatif dari aksi manajemen laba. Perusahaan yang meporkan informasi keuangan dengan kualitas tinggi maka akan cenderung lebih akuntabel sehingga akan kualitas akrual yang dilakukan juga semakin baik dan mengurangi tindakan tidak etis seperti tidak melakukan manajemen laba yang tinggi. Hasil ini memberikan informasi bahwa pengungkapan laporan berkelanjutan yang lebih kompleks dapat mendukung tindakan positif yang dilakukan oleh perusahaan.

Sejarah dan Perkembangan Laporan Berkelanjutan

Dalam perspektif historis, pengembangan dan fokus dari laporan berkelanjutan memiliki beberapa bagian (Hahn dan Kühnen, 2013). Pada awal tahun 1970an laporan keuangan tradisional di negara barat terkadang dilengkapi dengan tambahan laporan sosial. Pada tahun 1980an ada perubahan fokus, sehingga pada tahun-tahun tersebut fokus akan isu lingkungan seperti emisi dan limbah yang menggantikan laporan sosial sebelumnya. Pada akhir 1990-an, melaporkan penelitian dan praktik semakin mempertimbangkan dimensi sosial dan lingkungan secara simultan dalam laporan bersama yang diterbitkan bersamaan dengan laporan keuangan tradisional. Sebagai contohnya pada tahun 1980-1991an di Australia ditemukan peningkatan pengungkapan sukarela pada laporan CSR, hal ini karena tekanan dari kenaikan jumlah kelompok yang peduli terhadap lingkungan (Fernandez-Feijoo et al., 2013). Tren ini dapat dihubungkan langsung dengan pengembangan penetapan standar sukarela oleh Global Reporting Initiative (GRI). Saat ini GRI dianggap sebagai "standar global de facto" untuk pelaporan keberlanjutan.

Perkembangan laporan keberlanjutan sudah diteliti oleh Sweeney dan Coughlan (2008) dengan meneliti laporan CSR dan tahunan dari 28 perusahaan FTSE4Good dari berbagai sektor. Dari hasil penelitian mereka maka terungkap pemangku kepentingan utama dari setiap sektor berbeda-beda, seperti dalam industri jasa keuangan, maka pemangku kepentingan merupakan karyawan dan yang kedua merupakan masyarakat, berbeda dengan industri medis dan telekomunikasi dengan pemangku kepentingan utama yaitu masyarakat dan yang kedua merupakan karyawan, berbeda lagi dengan industri kesehatan, kecantikan dan ritel yang tidak memiliki pemangku kepentingan utama. Sedangkan, untuk industri minyak dan gas bumi maka lingkungan yang merupakan pemangku kepentingan utama. Beragam pemangku kepentingan yang berbeda akan mendorong pengungkapan yang berbeda pada laporan tahunan. Perusahaan yang lebih memiliki pemangku kepentingan utama lingkupan seperti industri minyak dan gas bumi, tentu akan memperbanyak pengungkapan mereka terhadap lingkungan. Perusahaan dengan pemangku kepentingan utama yaitu masyarakat seperti industri medis dan telekomunikasi maka akan lebih banyak pengungkapan di bidang sosial.

Selain itu Gamerschlag et al., (2011) yang melakukan penelitian di Jerman untuk periode 2005-2008 dan penelitian yang dilakukan Fernandez-Feijoo et al., (2013) melakukan penelitian untuk menemukan bagaimana tekanan dari stakeholders terhadap pengungkapan CSR atau laporan berkelanjutan, dengan data dari 1047 perusahaan pada tahun 2009-2010 dari beragam negara yang ada dalam database GR , mengungkapkan bahwa perusahaan yang semakin mendapat tekanan dari kelompok yang memperdulikan lingkungan maka akan semakin banyak mengungkapkan laporan keberlanjutan berbasis lingkungan seperti mereka yang berada dalam industri yang berhubungan dengan konsumen dan industri penyedia energi, sedangakan perusahaanperusahaan di sektor jasa karena tidak mendapatkan tekanan dari kelompok yang 
memperdulikan lingkungan akan mengungkapkan lebih sedikit informasi laporan berkelanjutan ke publik. Penelitian Fernandez-Feijoo et al., (2013) juga mengungkapkan bahwa pentingnya tekanan dari eksternal untuk pengungkapan laporan keberlanjutan. Banyak negara juga sudah sangat dengan baik mengungkapkan pertanggujawaban sosial mereka seperti AS, Jepang, Swedia, Firlandia, Brasil, Spanyol dan banyak negara lain.

Faktor-faktor yang Menyebabkan Luasnya Pengungkapan Laporan Berkelanjutan

Berdasarkan tinjauan literatur dari Hahn dan Kühnen (2013) dan Dienes et al., (2016) maka terdapat 3 topik yang menentukan diungkapkanya pelaporan keuangan: antara lain: ukuran perusahaan dan performa keuangan, kinerja sosial dan lingkungan, serta struktur kepemilikan.

a. Ukuran perusahaan dan performa keuangan. Ukuran perusahaan pada penelitian sebelumnya sering menunjukkan hubungan positif dengan adopsi pengungkapan laporan berkelanjutan. Hal ini karena perusahaan yang berukuran besar semakin berdampak lebih luas, sehingga diperlukan pengungkapan yang lebih luas terhadap perusahaan dengan ukuran besar. Dienes et al., (2016) menunjukkan bahwa perushaan dengan ukuran kecil dan menengah tidak terlalu mengungkapkan laporan berkelanjutan, karena biaya untuk melaporkan menjadi biaya yang tidak ekonomis dibandingakn manfaat yang didapatkan.

Performa keuangan yang sering diasumsikan dengan profitabilitas dapat menjadi aspek untuk meningkatkan kemampuan dan fleksibilitas perusahaan untuk menanggung biaya pelaporan keberlanjutan dengan demikian maka perusahaan yang memiliki profitabilitas tinggi maka akan semakin mampu untuk meningkatkan kualitas laporan keberlanjutan yang mereka miliki. Hasil ini didukung oleh penelitian Marquis dan Qian (2014) dan Vitezic' et al., (2012) yang menunjukkan pengaruh positif pada pengungkapan CSR. Namun hasil dari penelitian Dienes et al., (2016),
Andrikopoulos et al., (2014), Fernando and Pandey (2012), dan Michelon (2011) menunjukkan bahwa profitabilitas tidak mempengaruhi pengungkapan laporan keuangan. Tingkat hutang, leverage, atau gearing yang tinggi dapat diasumsikan untuk mengurangi kemampuan dan fleksibilitas perusahaan untuk menanggung biaya pelaporan. Pelaporan keberlanjutan dapat digunakan untuk melegitimasi kegiatan perusahaan terhadap kreditor dan pemegang saham, sehingga memberikan insentif untuk terlibat dalam pelaporan.

b. Kinerja sosial dan lingkungan. Pengukuran kinerja ini sering dilakukan dengan beberapa cara antara lain: melihat denda pelanggaran lingkungan yang dibayarkan oleh perusahaan, data pembuangan polusi aktual atau pengukuran kinerja keberlanjutan dengan indeks tertentu seperti Dow Jones Sustainability Index. Perusahaan yang ingin memberikan sinyal positif kinerja mereka terhadap sosial maupun lingkungan, maka akan semakin banyak melakukan pengungkapan laporan berkelanjutan dengan baik. Perusahaan yang memiliki performa lingkungan yang buruk juga diindikasikan akan melakukan pengungkapan yang lebih banyak untuk mendapatkan legitimasi dari stakeholders.

c. Struktur kepemilikan. Terdapat beberapa penelitian yang mengukur struktur kepemilikan dengan perusahaan yang terdaftar di bursa saham, kepemilikan pemerintah, kepemilikan terkonsentrasi atau tersebar serta kepemilikan asing. Perusahaan yang terdaftar dalam bursa saham akan lebih mengikuti peraturan tertentu, mengadopsi praktik yang lebih baik dibandingkan dengan kompetitor, serta mengatasi tekanan dari pemangku kepentingan sehingga akan lebih banyak mengungkapkan laporan berkelanjutan. Perusahaan yang dimiliki oleh pemerintah akan lebih mengungkapan laporan berkelanjutan dengan baik. Perusahaan dengan kepemilikan yang terkonsentrasi maka akan menghambat pelaporan keberlanjutan karena pemegang saham yang dominan sudah memiliki akses informasi yang relevan. Perusahaan dengan kepemilikan asing 
perlu untuk mengurangi asimetri informasi, sehingga sangat diperlukan pengungkapan laporan berkelanjutan yang baik. Hasil penelitian ini didukung oleh penelitian Andrikopoulos et al., (2014) dan Sharif dan Rashid (2014)

Berdasarkan tinjauan literatur dari Hahn dan Kühnen (2013) juga terdapat faktor eksternal yang mempengaruhi pengungkapan laporan keuangan seperti visibilitas perusahaan, afiliasi sektor, negara asal dan persyaratan hukum.

a. Visibilitas perusahaan. Penelitian sebelumnya menggunakan pengukuran banyaknya paparan media, posisi rantai pasokan dan aspek merek. Pada aspek paparan media, apabila perusahaan semakin banyak diberitakan di publik, maka akan semakin tinggi pelaporan berkelanjutan yang dilakukan oleh perusahaan. Dalam rantai pasokan apabila perusahaan berinteraksi langsung dengan konsumen, maka perusahaan akan semakin visibel sehingga perlu meningkatkan pengungkapan laporan keuangannya. Brand perusahaan yang sama dengan nama perusahaan juga akan lebih visibel oleh publik sehingga pengungkapan laporan kebelanjutan lebih banyak dilakukan. Hasil penelitian ini didukung oleh penelitian yang menunjukkan jumlah paparan media di jurnala dan majalah seperti Wang et al., (2013) dan Michelon (2011) dan atau peringkat surat kabar tertentu oleh Gamerschlag et al., (2011).

b. Afiliasi sektor, negara asal dan persyaratan hukum. Perusahaan dari industri yang berpengaruh terhadap lingkungan dan sosial maka akan meningkatkan pelaporan keberlanjutannya. Negara dan hukum setiap wilayah memiliki perbedaan, sehingga mempengaruhi pengungkapan laporan keuangan yang perlu dilakukan.

Pentingnya Pengungkapan Berkelanjutan di Perguruan Tinggi

Berdasarkan pembahasan sebelumnya maka laporan berkelanjutan sudah berkembang sejak tahun 1980an, dan terus berkembang dengan pedoman GRI dalam perumusan laporan berkelanjutan. Laporan berkelanjutan memerlukan transparansi dari organisasi yang akan melaporkannya. Kehadiran laporan berkelanjutan diharapkan dapat membantu untuk mencapai SDGs. Dengan demikian maka pentingnya dilakukan pelaporan berkelanjutan di seluruh sektor, termasuk sektor pendidikan di Perguruan Tinggi.

Penguatan alasan untuk diperlukannya pelaporan berkelanjutan di Perguruan Tinggi dikuatakan dengan data hasil penyebaran kuisioner kepada pihak-pihak dalam intansi Perguruan Tinggi maupun diluar Perguruan Tinggi, untuk mengetahui seberapa perlu pengungkapan laporan berkelanjutan di Perguruan Tinggi. Hasilnya maka 70\% responden mendukung agar informasi terkait aspek ekonomi, lingkungan dan sosial dari Perguruan Tinggi dilaporkan secara terpisah dalam bentuk suatu laporan sendiri. Sebagian besar responden yaitu 60\% mendukung untuk mengungkapkan sektor sosial sebagai poin utama, hal ini karena Perguruan Tinggi lebih banyak berhubungan dengan sektor sosial dibandingkan dengan sektor lingkungan dalam aktivitas bisnisnya. Namun, secara umum baik sektor sosial dan lingkungan perlu diungkapkan dalam laporan berkelanjutan. Perguruan Tinggi juga memiliki sumberdaya yang memahami laporan keberlanjutan, karena di dalam Perguruan Tinggi banyak akademisi yang telah memahami laporan berkelanjutan. Dengan demikian dapat dibuat laporan berkelanjutan di tingkat Perguruan Tinggi, yang dapat pula menjadi sarana transparansi Perguruan Tinggi serta menjadi contoh untuk organisasi lain yang ingin menerapkan laporan berkelanjutan pula.

Hasil ini juga sesuai dengan pembahasan sebelumnya bahwa pengungkapan transparansi akan mengurangi tindakan tidak etis yang dilakukan oleh pihak manajemen, sehingga pihak Perguruan Tinggi juga turut tidak lepas dari tindakan tidak etis sehingga perlu dilakukan pengungkapan laporan keuangan berkelanjutan yang baik, untuk meminimalkan tindakan tidak etis yang dilakukan oleh Perguruan Tinggi baik dilingkungan Perguruan Tinggi maupun diluar Perguruan Tinggi. Sesuai dengan pembahasan sebelumnya juga maka terdapat 3 topik yang menentukan diungkapkanya pelaporan keuangan termasuk di Perguruan Tinggi: 
antara lain: ukuran perusahaan dan performa keuangan, kinerja sosial dan lingkungan, serta struktur kepemilikan.

a. Ukuran perusahaan dan performa keuangan. Ukuran perusahaan pada penelitian sebelumnya sering menunjukkan hubungan positif dengan adopsi pengungkapan laporan berkelanjutan. Banyak Perguruan Tinggi pada saat ini memiliki ukuran yang besar, hal ini tentu mendorong semakin besarnya pengaruh Perguruan Tinggi terhadap lingkungan maupun sosial sehingga perlu untuk melakukan pengungkapan laporan berkelanjutan. Performa keuangan pada Perguruan Tinggi, terutama Perguruan Tinggi yang BLU atau PTN-BH maka semakin tinggi performa keuangan yang mereka miliki, karena mereka memiliki otonomi untuk mengatur keuangan mereka sendiri. Dengan demikian tentu harus semakin besar diharuskan untuk melakukan pengungkapan laporan berkelanjutan.

b. Kinerja sosial dan lingkungan. Perguruan Tinggi dengan semakin luas ukurannya serta mereka merupakan sektor publik, sehingga mereka perlu untuk melakukan pengungkapan laporan berkelanjutan. Karena Perguruan Tinggi perlu untuk melakukan beragam tindakan terhadap sosial dan lingkungan yang ada di sekitar Perguruan Tinggi.

c. Struktur kepemilikan. Pada saat Perguruan Tinggi masih menjadi Satuan Kerja maka pertanggungjawaban utama terhadap tindakan yang mereka lakukan masih terpusat kepada Kemetrian, sehingga tidak terlalu perlu melakukan pengungkapan laporan berkelanjutan. Akan tetapi dengan status Perguruan Tinggi yang menjadi BLU atau PTN-BH maka suatu Perguruan Tinggi memiliki otonomi tersendiri untuk mengelola keuangan yang mereka punya, sehingga harus semakin transparan dalam mengungkapkan pendanaan dan tindakan yang mereka lakukan, yang berdampak pada lingkungan dan sosial.

Berdasarkan tinjauan literatur dari Hahn dan Kühnen (2013) juga terdapat faktor eksternal yang mempengaruhi pengungkapan laporan keberlanjutan Perguruan Tinggi seperti visibilitas perusahaan, afiliasi sektor, negara asal dan persyaratan hukum.

a. Visibilitas perusahaan. Penelitian sebelumnya menggunakan pengukuran banyaknya paparan media yang diterima oleh Perguruan Tinggi. Pada zaman modern ini maka tindakan perusahaan akan semakin tampak, sehingga perlu pengungkapan laporan berkelanjutan sebagai aspek transparansi, dan menklarifikasi informasi negatif tentang Perguruan Tinggi.

b. Afiliasi sektor, negara asal dan persyaratan hukum. Pada saat ini Indonesia dan hukum Indonesia sangat mendorong untuk dilakukan pengungkapan laporan berkelanjutan, karena negara Indonesia merupakan bagian PBB yang turut mendukung terwujudnya SDGs. Dengan demikian, diperlukan pengungkapan laporan berkelanjutan dalam berbagai sektor termasuk Perguruan Tinggi, sehingga mampu mencapai tujuan tersebut.

\section{Kesimpulan}

Laporan berkelanjutan muncul karena pada beberapa tahun terakhir secara umum industri lebih sensitif terhadap lingkungan dan sosial, dengan semakin tinggi level pengungkapan yang dilakukan. Pengungkapan laporan berkelanjutan memerlukan transparansi, sehingga banyak manfaat yang bisa didapatkan dari berbagai stakeholders. Laporan berkelanjutan mengacu pada standar GRI.

Pengungkapan laporan berkelanjutan dalam setiap organisasi tergantung pada pemangku kepentingan utama dalam organisasi tersebut termasuk tekanan dari eksternal. Faktorfaktor yang mendorong organsisasi dalam mengungkapkan laporan berkelanjutan dapat ditinjau dari tiga topik utama antara lain: ukuran perusahaan dan performa keuangan, kinerja sosial dan lingkungan, serta struktur kepemilikan. Selain itu terdapat faktor eksternal yang mendukung pengungkapan laporan berkelanjutan antara lain visibilitas perusahaan, afiliasi sektor, negara asal dan persyaratan hukum. Dengan demikian maka dapat dilihat apakah faktor-faktor ini 
mendukung terselenggaranya

berkelanjutan di Perguruan Tinggi.

\section{Saran}

Kehadiran laporan berkelanjutan diharapkan dapat membantu untuk mencapai SDGs. Dengan demikian maka pentingnya dilakukan pelaporan berkelanjutan di seluruh sektor, termasuk sektor pendidikan di Perguruan Tinggi. Berdasarkan hasil kuisioner maka ditunjukkan sebagian besar responden menginginkan dilakukannya pengungkapan laporan keuangan di tingkat Perguruan Tinggi. Dari keseluruhan faktor baik internal maupun eksternal sangat mendukung untuk diwajibkannya pengungkapan laporan keberlanjutan di tingkat Perguruan Tinggi terutama Perguruan Tinggi yang memiliki status sebagai BLU atau PTN-BH. Bahkan Perguruan Tinggi dapat menjadi percontohan kepada berbagai organisasi dalam penerapan laporan berkelanjutan, sehingga menjadi tonggak utama dalam mewujudkan SDGs dalam berbagai sektor di Indonesia.

\section{Daftar Referensi}

Alisjahbana, A. 2018. Menyongsong SDGs Kesiapan Daerah-Daerah di Indonesia. Bandung: Unpad Press.

Andrikopoulos, A., Samitas, A., and Bekiaris, M. 2014. Corporate social responsibility reporting in financial institutions: evidence from Euronext. Research in International Business and Finance, 32: 27-35.

Anugerah, E. G., Saraswati, E., and Andayani, W. 2018. Quality of Disclosure and Corporate Social Responsibility Reporting Practices in Indonesia, Jurnal Akuntansi, Vol. 12(3): 337353.

Cooper, D. J., and Morgan, W. 2008. Case study research in accounting. Accounting Horizons, Vol. 22(2): 159-178.

Deegan, C. 2004. Financial Accounting Theory. Australia: McGraw-Hill.

Dienes, D., Sassen, R., and Fischer, J. 2016. What are the drivers of sustainability reporting? A systematic review. Sustainability Accounting, Management and Policy Journal, Vol. 7(2): 154-189.
Fernandez-Feijoo, B., Romero, S., and Ruiz, S. 2013. Effect of Stakeholders' Pressure on Transparency of Sustainability Reports within the GRI Framework. Journal of Business Ethics, 122(1).

Fernando, A.A.J., and Pandey, I.M. 2012. Corporate social responsibility reporting: a survey of listed Sri Lankan companies. Journal of International Business and Entrepreneurship Development, Vol 6 (2): 172-187.

Gamerschlag, R., Möller, K., and Verbeeten, F. 2011. Determinants of voluntary CSR disclosure: empirical evidence from Germany. Review of Managerial Science, Vol. 4(5): 233-262.

Global Reporting Initiative. 2019. What is sustainability reporting? (Retrieved from: https://www.globalreporting.org/informati on/sustainabilityreporting/Pages/default.as $\mathrm{px})$.

Hahn, R., and Kühnen, M. 2013. Determinants of sustainability reporting: a review of results, trends, theory, and opportunities in an expanding field of research. Journal of Cleaner Production, 59: 5-21.

Joseph, G. 2012. Ambiguous but tethered: An accounting basis for sustainability reporting. Critical perspectives on Accounting, 23: 93106.

Kim, Y., Park, M.S., and Wier, B. 2011. Is earnings quality associated with corporate social responsibility? The Accounting Review Vol. 87(3): 761-796.

Martínez-Ferrero, J., Garcia-Sanchez, I. M., and Cuadrado-Ballesteros, B. 2013. Effect of Financial Reporting Quality on Sustainability Information Disclosure. Corporate Social Responsibility and Environmental Management, Vol. 22(1): 45-64.

Marquis, C., and Qian, C. 2014. Corporate social responsibility reporting in China: symbol or substance? Organization Science, 25(1): 127-148.

Merriam, S. B., and Tisdell, E. J. 2015. Qualitative research: $A$ guide to design and implementation. John Wiley \& Sons.

Michelon, G. 2011. Sustainability disclosure and reputation: a comparative study, Corporate Reputation Review, Vol. 14(2): 79-96. 
Miles, M.B and Huberman A.M. 1984. Analisis Data Kualitatif. Terjemahan oleh Tjetjep Rohendi Rohidi. Jakarta: Perguruan Tinggi Indonesia.

Moleong, L. J. 2005. Metodologi Penelitian Kualitatif. Bandung: Remaja Rosdakary.

Nazari, J. A., Herremans, I. M., and Warsame, H.A. 2015. Sustainability Reporting: External Motivators and Internal Facilitators, Corporate Governance, Vol. 15(3): 375-390.

Sekaran, U., and Bougie, R. 2013. Research Methods for Business: a Skill Building Approach, 6th edition. United Kingdom: John Wiley \& Sons Ltd.

Sharif, M., and Rashid, K. 2014. Corporate governance and corporate social responsibility (CSR) reporting: an empirical evidence from commercial banks (CB) of Pakistan. Quality \& Quantity, 48 (5): 25012521.

Sun, N., Salama, A., Hussainey, K., Habbash, M. 2010. Corporate environmental disclosure, corporate governance and earnings management. Managerial Auditing Journal 25(7): 679-700.

Sustainable Development Solutions Network. 2018. University Commitment to the Sustainable Development Goals (retrieved from: http://ap-

unsdsn.org/regionalinitiatives/universitiessdgs/university-commitment/).

Sweeney, L., and Coughlan, J. 2008. Do different industries report corporate social responsibility differently? An investigation through the lens of stakeholder theory. Journal of Marketing Communications, 14(2): 113-124.

United Nations (UN). 2015. Transforming Our World: the 2030 Agenda for Sustainable Development (Retrieved from: http://www.un.org/ga/search/view_doc.as p? symbol=A/RES/70/1\&Lang=E).

Vitezic, N., Vuko, T, and Mörec, B. 2012. Does financial performance have an impact on corporate sustainability and CSR disclosure: a case of Croatian companies. Journal of Business Management, 5: 48-55.
Wang, J., Song, L., and Yao, S. 2013. The determinants of corporate social responsibility disclosure: evidence from China. The Journal of Applied Business Research, 29(6):1833-1848.

Wijethilake, C. 2017. Proactive sustainability strategy and corporate sustainability performance: The mediating effect of sustainability control systems. Journal of Environmental Management, 196: 569-582.

Yip, E., Van Staden, C., Cahan, S. 2011. Corporate social responsibility reporting and earnings management: The role of political costs. Australasian Accounting Business and Finance Journal, 5(3): 17-34. 